ELORE (ISSN 1456-3010), vol. $13-1 / 2006$.

Julkaisija: Suomen Kansantietouden Tutkijain Seura ry. Taitto: Jukka Talve. [http://cc.joensuu.fi/ /oristi/1_06/pel1_06.pdf]

\title{
Column:
}

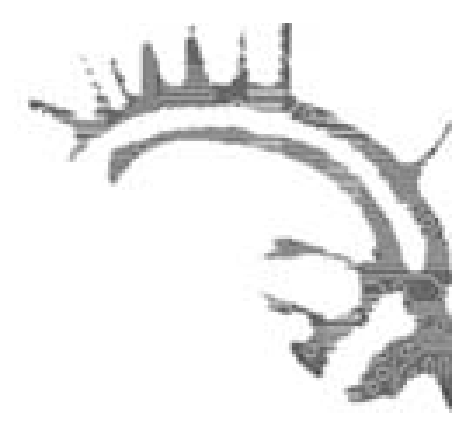

\section{The Fragility of Goodness}

\author{
Ulla-Maija Peltonen
}

Eric Hobsbawm has brought to our attention a harrowing fact of $20^{\text {th }}$-century civilization: barbarism has increased and is constantly increasing. This barbarism is manifested in the past century's civil wars, concentration camps, racial segregation, ethnic cleansing and countless other human rights violations. As a result, the lives of nearly 190 million people have been ruthlessly taken. Hobsbawm has reflected upon the mechanisms that enable people to think and act barbarically, noting that the conditions for barbarism are societal rather than psychological. Jacques Julliard refers to the new barbarism as the "new fascism" or the "new cruelty". Umberto Eco, on the other hand, refers to the phenomenon as "Ur-fascism".

In Hobsbawm's view, moral institutions and moral models of behaviour are a characteristic of civilization, or say, cultural human beings. These institutions and models which all societies use to regulate relationships among their members and with other societies have, according to Hobsbawm, crumbled. The ideals once inherited from the Enlightenment - liberty, fraternity and equality - have turned against themselves. What happens when traditional restraints no longer exist? The acts of barbarism committed during the war in Bosnia were brought about by a conscious effort to turn the conflict into an ethnic war. Nationalistic aims quickly give way to a totalitarianism which assumes racist and aggressive forms. Julliard has stressed that the cruelty of which we speak is a gospel of hatred or a culture of hatred which is not culture in the proper sense of the word. The culture of hatred goes hand in hand with a form of hatred hostile to culture. This culture of hatred is characterized by a desire to halt the advance of humanity, a desire to destroy culture by starting with the destruction of art, science, and education. What we have then is a barbarism that is learned, conscious, and systematically carried out.

We need to consider just how we reach the point where we resort to ethnic categorization: because you are a Serb, you must hate the Croats, or you will die. Or, in the case of Finland in 1918: because you are a White, you must hate the Reds, or you will die. In ethnic conflicts the opposition is thoroughly dehumanized. In his discussion of the rise of concentration camps during the Second World War, Theo- 


\section{Ulla-Majua Peltonen}

dor W. Adorno has underscored the destructiveness of severity as an educational ideal. An idealized severity signifies an indifference to human suffering. For example, when the Jews of Vilnius were forced to bury other Jews in the concentration camp, they were not allowed to use the terms "deceased" or "victim". They were only allowed to use the word "corpse". Grieving the dead was strictly forbidden, and those caught weeping were promptly beaten. People who treat themselves with severity can also be severe towards others. Such brutality exemplifies a devotion to efficiency devoid of substance. In other words, if human beings make themselves machine-like, they will also treat other human beings as machines.

Yet, even amidst acts of cruelty and evil, there lurks a near invisible virtue. In his book, The Fragility of Goodness, philosopher Tzvetan Todorov discusses acts of goodness in Bulgaria in 1943. Aside from Denmark, Bulgaria was the only Nazicontrolled European country where the deportation of Jews was resisted so unanimously that the holocaust was prevented, although there was no official policy regarding protection of the Jews. Those who fought against the deportations worked on different levels, independently and unaware of their common solidarity. Nevertheless, this conviction gradually penetrated the entire society - with considerable results.

If examined carefully, oral histories of wars and political turmoil invariably reveal acts of goodness amidst broader accounts of evil and callousness. For example, the oral history of Finland's bloody Civil War of 1918 is also interspersed with fragmented accounts of acts of generosity and self-sacrifice. Yet all these acts had far-reaching consequences. Numerous narratives tell of an influential neighbour who rescued someone from the firing squad or who brought food to a hungry family. To cite an example from the Soviet era, one of my informants, an eighty-year-old Ingrian man, claims to have survived Stalin's prison camps not only by his wits but also through the goodness of others. Time and again, quick-thinking individuals grasped the seriousness of the situation and were willing to help those in need. Such sacrifice demonstrates a firm belief in life. Fragile goodness should be cherished as a heartening example of our humanity. Perhaps we wouldn't even be here if such goodness had never existed.

\section{Docent Ulla-Maija Peltonen, The Folklore Archives, The Finnish Literature Society (SKS).}

